\title{
Logistics Distribution Problems and Countermeasures under E-commerce Environment
}

\author{
Guo Xiwei \\ School of Economic and Management \\ Shengyang Aerospace University \\ Shengyang, China \\ Guo Xiwei@sau.edu.cn
}

\begin{abstract}
With the gradual improvement of China's market economy system, modern logistics industry certainly plays a primary role in economic development, which is also a vital indicator to weigh national and regional comprehensive capabilities. E-commerce connects the electronic information technology with business conducts, and bases on the brand new business operation of Internet. With the deepening of reform and opening up, China's modern logistics industry develops and grows in understanding the self, finding inadequacies, doing inexhaustible researches and making constant improvements. This will definitely have a positive effect on the growth of domestic e-commerce, and thus stimulate the domestic economy to enter a new era.
\end{abstract}

Keywords-E-commerce; Modern Logistics; Service Pattern; Logistics Distribution

\section{INTRODUCTION}

Modern logistics has become an integral part of urban economy, regional economic growth and national economic development. In today's rapid progress of ecommerce, the logistics industry has increasingly been a support that can't be ignored. Modern logistics involves many fields such as transportation, storage, assembly, handling, distribution processing, distribution and modern information technology. Therefore, building an efficient low-cost logistics system is an important link of realizing e-commerce. Logistics and distribution system determines the development level of e-commerce, so the logistics distribution system and its governance under e-commerce are extremely important for the business success.

With the constant development of information technology along with changes in people's production and management philosophy, contemporary society is gradually entered an era of growing network transactions. E-commerce is a product of the information, which is using a new business operation to provide new trading form one after another to the electronic information era. The e-commerce success should integrate the capital flow, information flow, business flow and logistics. Logistics is the most special one, which is more and more important to the successful operation of e-commerce. Logistics not only promotes the healthy rapid growth of domestic ecommerce, but also reduces business costs and improves distribution efficiency as e-commerce enterprises.
Contemporary e-commerce logistics distribution has the problems such as high logistics distribution costs, low distribution quality, low level of modern information and excessive materials. E-commerce enterprises mainly adopt the logistics strategy of improving the quality of logistics distribution, maintain the user's reliability with the best service concept; achieve the customer satisfaction services with the minimum operating costs; enhance the logistics information level of e-commerce businesses, and keep good coordination between the smoothing of logistics subsystems and logistics sub-systems.

\section{CURRENT SituATION AND PROBLEMS OF CHINA'S E-COMMERCE LOGISTICS DISTRIBUTION DEVELOPMENT}

\section{A. Current Situation of China's E-commerce Logistics Distribution Development}

At present, China's e-commerce trading volume increased by $40 \%$ annually, breaking the record of 8 trillion Yuan in 2012. As e-commerce develops rapidly, various logistics patterns generate, a type of new logistics form appears because of the integration of contemporary logistics and e-commerce, namely, the e-commerce logistics distribution form.

Currently China mainly adopts the logistics distribution patterns of self-support logistics and third party logistics.

\section{1) Self-support logistics distribution pattern}

At present, Chinese production, circulation or comprehensive enterprises generally adopt this logistics distribution pattern. The form is a self-financing logistics system organized by enterprises as well as a distribution pattern from user ordering goods to arriving at users without third party involvement. Its general approach is to set up warehouses and distribution centers in the crowd areas.

\section{2) Third-party logistics distribution pattern}

Third-party logistics pattern opposites to self-support logistics, also known as "outsourcing logistics" or "contract logistics". Both trading parties are a power distribution network to complete the distribution business being entrusted to third parties outside the supply side and the demand side and reach the destination. 


\section{B. Problems of China's E-commerce Logistics Distribution Development}

In practice, although these two patterns have been accepted and applied, there are still many problems in practice and in the process of e-commerce logistics distribution, which are mainly reflected in the following aspects:

Study on logistics is not systematic and deep enough. Great progress has been made in current theory and application of logistics management, resulting in a lot of theories. While the Chinese logistics has just had access to new theories, it is necessary to further digest, understand and transform them into practical productivity.

E-commerce logistics enterprises are featured by imperfect infrastructure as well as insufficient applications of new skills and new facilities. Many e-commerce logistics enterprises lack a good understanding of the concept, status and role of modern logistics. Dilapidated facilities and low electronic level of logistics management still cannot meet the rapid development needs of ecommerce.

There are no laws to abide by". There is almost no law and regulation for e-commerce logistics system, so the logistics enterprises particularly need relevant laws and regulations to standardize the logistics behaviors. This is reflected in the financial system, property rights transfer system, use of the able person, market control system, social security system and so on. Logistics system is a social system that covers many regions and industries, which will definitely require various logistics resources to coordinate between external and internal enterprises as well as between enterprises and the market. Since the reforms have yet succeeded, reallocation based on economic and logistics resources will affect the rational principle of enterprises.

\section{CAUSES AND BASIC SOlutions OF ChINA's E- COMMERCE LOGISTICS DISTRIBUTION PROBLEMS}

\section{A. Causes of China's E-commerce Logistics Distribution problems}

1) Enterprises have insufficient understanding of $e$ commerce logistics and low attention degree

At present, China's e-commerce functions are still limited to information flow, and little attention is paid to ecommerce logistics distribution. Many enterprises lack sufficient understanding of modern logistics in transport industry and economic benefits increase. They think logistics is transportation. Their understanding of logistics remains stagnant in freight, storage and other traditional aspects.

2) E-commerce logistics distribution infrastructure is inadequate

Logistics infrastructure consists of roads, ports, railways, airports and so on. In recent years, China's Ministry of Finance has increased the investment in the construction of logistics infrastructure. However, due to restraints of old ideas ("attaching importance to production and neglect circulation"), China's logistics infrastructure remains small in the overall size, some logistics facilities still lag behind with low utilization rate and monotonic functions, and thus there is no way to achieve the mechanization and automation.

3) The logistics distribution cost is high

While the logistics cost account for about $9 \% \sim 10 \%$ of the total cost in developed countries, China's logistics cost account for about $18 \%$ of the total cost; in addition, China' s annual economic losses amount to 27 quintillion dollars.

In China, today's e-commerce business logistics distribution not only faces wholesalers and retailers, but also faces the bulk of consumers. At present, the diverse needs of consumers enable logistics distribution to be featured by small batch, multiple categories and door to door, resulting in complex and cumbersome distribution activities and high logistics cost.

\section{4) The distribution channel is unsound}

At present, China's e-commerce enterprises mainly have three distribution channels. The first channel is to establish their own logistics distribution system together with advanced logistics facilities and equipment to complete the introduction to logistics. However, it costs a lot of money to establish a distribution network, and there is no scale effect. The second channel is that e-commerce manufacturers cooperate with third-party distribution companies, enter into the distribution regulations, and outsource their own distribution businesses to other companies. In the cooperation process, there are differences in business management between two companies, and thus hinder the organic combination of electronic information technology and distribution operating system, causing untimely distribution, shipping delay or failure delivery and increased customer dissatisfaction. The third channel is online shopping to pay at the nearest store pickup. This channel has greatly increased the store capital, enables enterprises to ignore the third profit source of logistics, fail to complete the "home delivery service", and thus reduce the service quality of ecommerce.

5) Business environment is relatively backward and the professional service degree is low

Many single-function logistics enterprises are featured by small scope of service, weak horizontal cooperation, failure to provide sound supply chain services and failure to meet customer needs in timeliness and service quality. Besides, the domestic enterprises lack sufficient supports for online shopping, and there are phenomena of mutual boycott and vicious competition.

\section{6) Professional technical talents are inadequate}

Modern logistics is a high-tech industry, so it is essential to employ scientific management methods, modern management system and high-quality logistics management talents. However, compared with the scale of foreign logistics education system, China has a relatively backward condition of logistics education, inadequate logistics system education and training system. Owing to inadequate e-commerce logistics distribution talents, the implementation of e-commerce distribution pattern is restricted, affecting the operation of e-commerce logistics distribution.

7) There is no uniform logistics distribution standard

Now logistics enterprises no longer have the phenomena of uneven distribution, price transparency and low price competition for online shopping. Besides, there 
is no unified standard for product packaging, labeling and other elements. Many logistics companies set the price within a fuzzy range, causing shopping site to have too high logistics costs and low customer transparency.

\section{8) Relevant policies and regulations are incomplete}

In China, e-commerce logistics distribution management system has not yet formed a complete legal system, and the government cannot give full play to the role of macro-control, resulting in serious logistics and resources waste. In addition, the social security system corresponding to e-commerce logistics distribution, market entry and exit system, dispute resolution process remain incomplete. However, the system defect has greatly hindered the enterprises' replacement of logistics resources and logistics efficiency.

\section{B. Basic Solutions of China's E-commerce Logistics Distribution problems}

As the network technology develops, e-commerce will inevitably become the main development trend, bringing new opportunities and challenges to the logistics operation of e-commerce. The acceleration of logistics distribution that conforms to e-commerce is the need of Chinese enterprises to participate in competition, which can narrow the gap with the logistics industry of developed countries. Therefore, the problems of China's e-commerce logistics distribution should be solved from the following aspects:

1) Raise public awareness of e-commerce logistics

Modern logistics has become increasingly prominent. Enterprises pay attention to changes in the external environment along with the promotion of e-commerce and e-commerce logistics. The government and enterprises should participate in the establishment of electronic information environment. The government should make large investment in highways, railways, aviation and information networks, in order to guarantee the smooth traffic and information flow, form a transportation network and information network covering the whole society, and provide a quality social environment for the development of e-commerce and modern logistics and supply. Moreover, enterprises should carry out commercial acts via the information network, provide users with express services, attract more manufacturers and enterprises, and enhance the competitiveness and profitability of enterprises, so as to promote the development of e-commerce and modern logistics.

2) Establish facilities that meet the needs of $e$ commerce logistics distribution

It is an important means to establish facilities that meet the needs of e-commerce logistics distribution, which can improve China's logistics development and international competitiveness. To improve basic e-commerce logistics facilities, it is essential to improve transport and communication facilities. In terms of transport, the government should intensify the construction and investment in highway, and strengthen the planning and management of logistics distribution center. In terms of information communication, the government should build "highway" via logistics information, make full use of information technology, accelerate the construction of lowcost logistics distribution and other favorable conditions, and speed up the construction of the Internet, in order to improve the efficiency of logistics activities.

\section{3) Improve the information level}

In order to achieve rapid and convenient e-commerce logistics, e-commerce enterprises and logistics enterprises are required to have higher information level and reach a maximum degree of information sharing. Logistics Information is data, standardization of logistics information collection, processing, transmission and storage, which is crucial for enterprises to fulfill their high level of integrated governance. By implementing the information of logistics distribution, the enterprises may give full play to the guiding advantages of information technology, link all aspects of e-commerce and logistics companies, track the goods information in a real-time and accurate manner, and timely give feedback, so as to better meet the consumer needs and provide consumers with better, efficient services.

4) Reasonably choose the logistics distribution pattern and effectively integrate the distribution capabilities

When e-commerce companies select the logistics distribution pattern, they shall consider the following factors: consumer regional distribution, types of goods, ecommerce service providers, distribution processes, logistics costs and inventory control. Enterprises should select appropriate distribution pattern according to their own development characteristics. If the enterprises have abundant financial resources, they may consider adopting self-support logistics pattern, and newly established SMEs shall adopt other patterns such as third-party logistics distribution, especially those SMEs with inadequate capital, business portfolio and experience.

5) Vigorously cultivate e-commerce logistics talents

When training logistics talents, combine theory with practice and focus on developing practical skills. On one hand, encourage to set the training pattern with combination of logistics students and their own characteristics, promote logistics education through various forms, and expand the logistics management pattern. On the other hand, vigorously develop vocational education, and transport a large number of practical logistics talents to logistics enterprises by creating logistics vocational and technical schools or opening training courses.

6) Give full play to macro-control role of the government

The government shall actively play its role in promoting the logistics development, support and finance the establishment of logistics distribution system under ecommerce environment. First of all, according to the decentralized management of domestic logistics industry chain, establish the national logistics institution or organization with coordination functions. Secondly, the government should develop the standardized logistics growth policy, set the overall logistics development goals, increase the investments in the logistics industry, unify the logistics development plan, and make scientific use of logistics infrastructure, in order to change the current irrational status of logistics industry. On this basis, China's logistics network shall promote the improvement of the overall logistics industry. 


\section{CONCLUSION}

E-commerce is inseparable from logistics distribution, whereas logistics distribution is essential for the implementation of e-commerce. Compared with foreign countries, China's e-commerce logistics starts late, develops slowly, and there is still a great gap with social demands. To stimulate the rapid development of domestic e-commerce logistics industry, it is essential to find out problems after careful implementation, propose viable solutions, and implement them. Under the government's strong support and guidance, change the uncoordinated, non-uniform logistics distribution of multiple management departments, and attach great importance to cultivation of relevant talents. According to China actual situation, the enterprises should choose the logistics distribution means that suit for its development, make full use of logistics information, automation, intelligence, network and flexibility, enable enterprises to gain the best economic benefits, and thus enhance the rapid stable development of China's e-commerce.

\section{REFERENCES}

[1] Guo Gaiying: Research on Logistics Distribution Problems and Countermeasures of China's E-commerce [J]. Modern Business, 2010 (20).

[2] Jiang Jiatian: Research on Development Status, Problems and Countermeasures of China's e-commerce logistics distribution [J], Market Modernization, 2012 (511).

[3] Han Yongqing: Analysis of China's Logistics Distribution of under e-commerce environment [J], Inner Mongolia Science Technology and Economy, 2010 (2).

[4] Zhou Shiren: Research on Logistics Distribution Patterns under Ecommerce [J], Logistics Sci-Tech, 2010 (11).

[5] Li Ying: Logistics Distribution Problems and Strategies under Ecommerce [J], China Management Informationization, 2013 (11).
[6] Wang Jian, Fang Jialin, Comparison of American, Japanese and European Modern Logistics Development and Enlightenment, Northeast Asia Forum, 2013 (02)

[7] Zhang Bingxuan: Research on Corporate Logistics Distribution Problems under E-commerce Environment [J], China Market, 2010 (49).

[8] Xin Hong: Research on E-commerce Logistics Distribution Problems and Countermeasures [J], China Business \& Trade, 2012 (4).

[9] Guo Honghe: Research on E-commerce Logistics Distribution Problems and Countermeasures [J], Northern Economy and Trade, 2012 (8).

[10] Chen Yanhui, Xu Guohua: A Logistics Distribution Pattern under E-commerce environment [J], Modern Electronics Technique, 2013 (19).

[11] Li Wei: Analysis of China's E-commerce Logistics Pattern and Selection Factors [J], Research \& Study, 2012 (8).

[12] Wen Longguang, Yi Weiyi: Measures to Promote the Development of E-commerce Logistics [J], Market Modernization, 2013 (09).

[13] BULLNHEIMER B.HARTL.R F.STRAUSS C. Anim proved ant system algorithm for the we hicle routing problem[J].Annals of Operations Research, 2013, $89: 319-328$ 。

[14] Sun Lingfang, Shen Jing, Xu Jinbo, Ji Zheng: Logistics Distribution Bottlenecks under E-commerce Environment $[\mathrm{J}]$ China Market, 2012 (28).

[15] Yu Fang: Research on Logistics Pattern under E-commerce Environment [J], Sci-Tech Information Development \& Economy, 2011 (6).

[16] PODILCHU K C I,DEL P EJ.DIGITAL water marking: algorithms and application [J].IEEE Signal Processing Magazine, 2001, 18 (4) : $33-46$ 